FROM THE EDITORS' DESK

\title{
From the Editors' Desk: Truth Rules, or the Upside of Bureaucracy
}

\author{
Steven M. Asch, MD, MPH \\ Palo Alto Veterans Affairs Healthcare System and Division of Primary Care and Population Health, Stanford, CA, USA.
}

J Gen Intern Med 33(7):979

DOI: $10.1007 / \mathrm{s} 11606-018-4453-3$

(c) Society of General Internal Medicine (This is a U.S. Government work and not under copyright protection in the US; foreign copyright protection may apply) 2018

$\mathrm{W}$ ho among us has not lamented the tyranny of the petty bureaucrat? The rules governing a general internist's life, from clinical documentation to hiring to research regulation, often seem like so much sand in the gears. Even Max Weber, the founder of the social science of organizations, famously lamented that bureaucracy's "iron cage" trapped individuals' creativity in pursuit of efficiency and order. ${ }^{1}$

But Weber also pointed out that rules are the best defense against authoritarianism and favoritism. The Chinese invented the neutral and meritocratic administrator in the Song dynasty. Enlightenment thinkers, rebelling against theocratic sources of legitimacy, crafted the idea of a government officialdom loyal first to scientific principles. Truth and unbiased inquiry would guide decisions, not the avarice of officeholders or the whims of kings. ${ }^{2}$

Our topsy-turvy times find this upside of bureaucracy under attack and the downside ascendant. Officials overseeing environmental research receive gifts from potential polluters but use agency rules to restrict the widest consideration of the data under the false flag of transparency. ${ }^{3,4}$ Before being forced to resign, the Centers for Disease Control (CDC) director purchases significant investments in one of the largest causes of disease. ${ }^{5}$ Officials there suggest to their underlings that use of the words "evidence-based" and "science-based," so dear to the Enlightenment architects of bureaucracy, might jeopardize programs' chances of getting in the federal budget. Thus, the sound of those words in our public debate muffles, falling from 129 mentions in the 2017 CDC budget proposal to 43 in 2018 according to an analysis in Science. ${ }^{6}$

Outside the government, the rules governing the validity of scientific inquiry fail to prevent flimsy findings from influencing that public debate. Vaccines do not cause autism, but it was weak peer review that allowed the opposite finding into the public sphere. ${ }^{7}$ A case series of 38 patients with chronic nonmalignant pain helped propel opiate prescriptions in the late 1980 s, and we still deal with the fallout today. ${ }^{8}$ The lay press' desire for counternarratives even when the evidence supports only one side fuels this problem. There is no need to give equal coverage to a publicity-seeking holistic cardiologist and the former CDC director after a measles outbreak highlights vaccine underuse. ${ }^{9}$

So pity the petty bureaucrat, and support the upside of bureaucracy. As clinicians, we must demand our government respect expertise and evidence in crafting the policies that affect our patients. As scientists, we must demand strict conflict of interest rules and the most neutral analyses for policymakers. As teachers (and yes, editors), we must ensure that balance is given only when balance is due and that evidentiary rules matter. As administrators, we must support the scientific work of peer review and public service with protected time. Truth will only rule when the rules are fair and fairly enforced.

Corresponding Author: Steven M. Asch, MD, MPH; Palo Alto Veterans Affairs Healthcare System and Division of Primary Care and Population Health, Stanford, CA, USA (e-mail: sasch@stanford. edu).

\section{Compliance with Ethical Standards::}

Conflict of Interest: : The author declare that he do not have a conflict of interest.

\section{REFERENCES}

1. Max Weber; Peter R. Baehr; Gordon C. Wells. The Protestant Ethic and the "Spirit" of Capitalism and Other Writings. Penguin. 2002, 132pp

2. Weber M., Henderson, A.M., and Parsons, T. The Theory of Social and Economic Organization. New York, Oxford University Press. 1947, 450pp

3. https://www.documentcloud.org/documents/4433878-Letter-to-EPADAEO.html accessed 4/9/18

4. Bastasch, Michael. Scott Pruitt will end EPA's use of 'secret science' to justify regulations. The Daily Caller. 2018

5. Branswell, Helen. CDC director's investment in tobacco, drug companies baffles ethics experts. Scientific American. 2018

6. Cohen, Jon. CDC word ban? The fight over seven health-related words in the president's next budget. Science. 2017

7. Godlee F, Smith J, Marcovitch H. Wakefield's article linking MMR vaccine and autism was fraudulent. BMJ 2011; 342 :c7452

8. Portenoy RK, Foley KM. Chronic use of opioid analgesics in nonmalignant pain: report of 38 cases. Pain. 1986 May;25(2):171-86

9. McCoy, Terrence. Amid measles outbreak, anti-vaccine doctor revels in his notoriety. The Washington Post. 2015 